The Medical Research Council Committee concludes that, despite these shortcomings, the protection measures were essentially right and, once brought into play, were applied decisively, and were adequate. It is convinced that it is in the highest degree unlikely that any harm has been done to anybody.

The chairman of the Atomic Energy Authority has accepted full responsibility for the accident, and at his request further inquiries are in hand to undertake a technical evaluation of information arising from the accident, and to review organization problems concerned with reactor operation.
A short, but convincing, note by the Authority gives several reasons why this accident could not happen with the Calder Hall or the new Electricity Authority reactors.

Much experience and information have been gained from the accident, without, so far as can be judged, any ill effects on humanity. We are fortunate in that the cause and history of the accident have almost certainly been traced, and we can be especially thankful for those much-criticized excrescences at the top of the ventilation stacks, the radioactivity filters.

W. Murgatroyd

\title{
OBITUARIES
}

\section{Dr. Gerty T. Cori}

Dr. Gerty T. Corr, who died at St. Louis, Mo., on October 26, was a most distinguished biochemist. In 1947, Prof. Carl F. Cori, her husband, and she shared with Prof. B. A. Houssay, of Argentina, the Nobel Prize for Medicine and Physiology.

Gerty Cori was born in Prague, Czechoslovakia, graduating in medicine from the German University in that city in 1920. In the year she graduated she married a fellow medical student, Carl Cori, by whom she later had one son. In 1922, Carl and Gerty Cori moved to the United States, becoming American citizens in 1928. Until 1931 they worked at the State Institute for the Study of Malignant Diseases at Buffalo, N.Y., and in 1931 they moved to St. Louis, where ultimately they both held professor. ships of biochemistry in the School of Medicine of Washington University.

Their principal researches have been in the field of carbohydrate metabolism, with particular reference to the mechanism of breakdown and building up of glycogen and the influence of hormones on the processes. In their early researches at Buffalo they discovered the 'Cori cycle', whereby lactic acid produced in mammalian muscle is converted to liver glycogen and thence can go via blood sugar to muscle glycogen and so back again to lactic acid. Their characterization of phosphorylase and their identification of the then unknown glucose-1-phosphate as the product of the action of the enzyme on glycogen under suitable conditions were of outstanding importance in the elucidation of pathways whereby glycogen is broken down and built up in muscle and liver. This discovery led to the first in vitro production of glyeogen, which took place in their laboratory. Before this could be done, they characterized a branching enzyme (amylo-1 : 4-1 : 6transglucosidase) in muscle which converts some $1: 4$ links of the amylose formed from glucose-1-phosphate, under the influence of phosphorylase, into $1: 6$ linkages, and thus produces a branched polysaccharidein this instance glycogen-from a straight-chain one, namely amylose. In conjunction with her pupils during the past few years, Gerty Cori has, despite a rapidly growing illness, developed an enzymic method for assessing the molecular architecture of glycogen. Using such methods, she has differentiated several types of glycogen-storage disease according to differences in the enzymes and abnormalities of the structure of the stored glycogen.

The researches of Gerty Cori and her colleagues concerning the influence of insulin on the enzyme hexokinase are still a matter for discussion, but undoubtedly they have given rise to much fruitful investigation regarding the fundamental action of insulin all over the world.

Gerty Cori was a charming hostess as well as an outstanding scientist, being a woman of wide general culture and interests. A brave woman, outstanding as a scientist among scientists, she has left a permanent record of herself in numerous laboratories, not only in publications but also in the wide influence she exerted on research in the difficult field of carbohydrate metabolism $\quad$ F. G. YounG

\section{Prof. J. A. S. Ritson, O.B.E.}

John Anthony Sydney Ritson, emeritus pro. fessor of mining in the University of London, died on October 16 at the age of seventy. He was born at Pelton, Co. Durham, on August 18, 1887, and was educated at Uppingham and the University of Durham.

As a Rugby player he was capped several times for England between 1910 and 1913 and never in later life lost his love for the game which so appealed to the 'Geordie' side of his temperament. In the First World War his crisp and firm appraisal of men and situations won him the command of the 12th Royal Scots, a regiment he led with dash and distinction from 1916 until 1919. His battle honours included the D.S.O. and bar, the M.C. and four 'mentions'. After a post-war period as H.M. Inspector of Mines, during which he served successively in Scotland, Yorkshire and South Wales, he was appointed to the chair of mining in the University of Leeds in 1923.

In 1935 he was made O.B.E., and in the following year took over the chair of mining at the Royal School of Mines (one of the three associated Colleges which form the Imperial College of Science and Technology, London). Here his love of manly sports, his directness of approach and the whole-hearted way in which he embraced the cause of his students won him a host of friends. His long memory for names and faces was a valuable asset in this connexion, since metal miners go out from the Royal School of Mines all over the world and international social contacts are important. In addition to his academic activities, he did valuable work on O.E.E.C., where he helped to generate post-war interests in the development and treatment of low-grade ore deposits. Part of the fruits of his work, in which he took an important role, was the institution of the first degree course in the world in mineral dressing, at the Imperial College. 